\title{
ROLE OF CEREBROPROTEIN HYDROLYSATE IN OUTCOME AND RECOVERY OF TRAUMATIC BRAIN INJURY
}

\author{
Ishwar Dayal Chaurasia1, Manish Parihar², Puspendra Gehlot ${ }^{3}$, Ansul Siroliya ${ }^{4}$, M. C. Songara ${ }^{5}$
}

${ }_{1}^{1}$ Assistant Professor, Department of Neurosurgery, Gandhi Medical College and Associated Hamidia Hospital, Bhopal, MP.

${ }^{2}$ Resident, Department of Surgery, Gandhi Medical College and Associated Hamidia Hospital, Bhopal, MP.

${ }^{3}$ Resident, Department of Surgery, Gandhi Medical College and Associated Hamidia Hospital, Bhopal, MP.

${ }_{4}^{4}$ Senior Resident, Department of Surgery, Gandhi Medical College and Associated Hamidia Hospital, Bhopal, MP.

5 Professor and HOD, Department of Surgery, Gandhi Medical College and Associated Hamidia Hospital, Bhopal, MP.

\section{ABSTRACT}

\section{BACKGROUND}

Traumatic Brain Injury (TBI) is a complex injury with a wide range of symptoms and disabilities, which can lead to a lifelong devastating effect on the patient and the family. Its (TBI) incident is increasing day-by-day. There is a need of better management in traumatic brain injury patient to reduce the mortality and associated with it. Cerebroprotein hydrolysate is a recent neurotrophic and neuroprotective drug which is in use for acute ischaemic strokes, vascular dementia, Alzheimer's disease and traumatic brain injuries with its proven potential.

Aims and Objectives- Our work aims to evaluate the effectiveness and safety of cerebroprotein hydrolysate in the management of brain injury patients.

\section{MATERIALS AND METHODS}

A randomised controlled trial used in the study and the sample size was taken for convenience during the study. This study was conducted on 200 patients and the patients were randomly divided into two groups. Group 1 (study group, n= 100) received cerebroprotein hydrolysate for $14-21$ days and Group 2 (control group, $n=100$ ) received only conventional therapy. Both the groups were assessed with GCS (Glasgow Coma Score), APACHE П (Acute Physiology and Chronic Health Evaluation II) scores and CT/ MRI Brain on admission and were compared in terms of degree of improvement on 14 - 21 days from the day of admission.

\section{RESULTS}

Patient on cerebroprotein hydrolysate was compared to conventional therapy (control) group. Patients with cerebroprotein hydrolysate showed statistical significance ( $p$ value $=0.001$ ) in regard to GCS and in terms of functional and cognitive outcome.

\section{CONCLUSION}

Our study concludes that the usage of cerebroprotein hydrolysate therapy can be safe and useful in traumatic brain injury in terms of functional and cognitive outcome with better recovery.

\section{KEYWORDS}

Cerebroprotein Hydrolysate, TBI- Traumatic Brain Injury.

HOW TO CITE THIS ARTICLE: Chaurasia ID, Parihar M, Gehlot P, et al. Role of cerebroprotein hydrolysate in outcome and recovery of traumatic brain injury. J. Evolution Med. Dent. Sci. 2018;7(18):2177-2180, DOI: 10.14260/jemds/2018/489

\section{BACKGROUND \\ 1. Primary- Mainly occurs at the moment of trauma.}

Traumatic Brain Injury (TBI) is the most common cause of disability and death as well as loss of productivity in resource limited settings, particularly in younger age groups ${ }^{[1]}$ of 1520 yrs. Traumatic brain injury is graded as mild, moderate and severe as per Glasgow Coma Scale (GCS). GCS 13-15 is termed mild and is mostly due to concussions and there is complete neurological recovery except short-term memory loss in few cases. GCS 9-12 is termed moderate- the patient is lethargic or stuporous. GCS 3-8 is termed severe- the patient is comatose and is unable to open eyes or follow commands. TBI is divided into two main categories-

'Financial or Other Competing Interest': None.

Submission 21-03-2018, Peer Review 17-04-2018,

Acceptance 23-04-2018, Published 30-04-2018.

Corresponding Author:

Dr. Ishwar Dayal Chaurasia,

\#31, Patrkar Colony,

Link Road No. 3,

Bhopal,

Madhya Pradesh.

E-mail: idc_3456@yahoo.co.in

DOI: $10.14260 /$ jemds $/ 2018 / 489$
2. Secondary- That develops after initial injury and produces effects that may continue for long time. ${ }^{[2]}$ The secondary injury process (includes excessive synthesis of nitric oxide and oxidative stress, microglia activation, local inflammation, disturbances of microcirculation, blood brain barrier dysfunction and delayed mechanism of cell death) leads in a vicious circle to disastrous consequences like neuronal necrosis, neuronal apoptosis, scare and/ or cyst/ hygroma formation, demyelination, disruption of morphofunctional uncoupling such as diaschisis. [3]

The most common causes of TBI are road traffic accidents (60\%), falls and construction (20 - 25\%), violence and sports injuries (10\%). It is estimated that near 1.5 to 2 million people are injured and about 1 million succumb to death every year in India. About 97,00,000 Indians are living with disability related to TBI. Various clinical trials have been undertaken to improve the survival and functional outcome in TBI. One potential concern has been that many of the agents examined have targeted one protein of the cascade of injury that occurs after TBI. 
These agents also have a time limited opportunity to provide neuroprotection and are rarely involved in the neurorestorative process. A potential agent that could provide both neuroprotection as well as means to facilitate fast recovery process is cerebroprotein hydrolysate.[4] Cerebroprotein hydrolysate is a recent neurotrophic and neuroprotective drug which is in use for TBI, stroke, vascular dementia and Alzheimer's disease etc. The purpose of this study is to describe the rationale for the choice of cerebroprotein hydrolysate.

\section{Aims and Objectives}

The aim of this study was to evaluate the effectiveness and safety of cerebroprotein hydrolysate in the management of traumatic brain injury patients.

\section{MATERIALS AND METHODS}

Randomised controlled trial used in the study and the sample size was taken for convenience during the study. This study was conducted from January 2016 to July 2017. 200 patients were included in this study and were randomly divided into two groups of 100 each. Group I (Study group) received cerebroprotein hydrolysate $60 \mathrm{~mL} / \mathrm{g}$ bid for $14-21$ days and Group II (Control group) received only conventional therapy. Both groups were assessed with GCS scoring, APACHE II scores and CT/ MRI brain scanning on admission and clinical evaluation which was compared with the degree of improvement on 14 days, i.e. 2 weeks and 21 days, i.e. 3 weeks from the day of admission.

\section{Statistical Analysis}

Chi-square test and student's t-test was undertaken for the statistical analysis. Software used is SPSS 18 for statistical analysis.

\section{Inclusion Criteria}

- Age eligible for study- 13 to 70 yrs. within $24 \mathrm{hrs}$. of trauma.

- Gender eligible for study- Both male and female.

- $\quad$ GCS 3 to 8 and 9 to 12 .

- $\quad$ Non-penetrating TBI.

- Reasonable expectation of completion of outcome of a network centre at 3 months post injury.

- Reasonable expectation of enrolment within 24 hours' time window post injury.

\section{Exclusion Criteria}

- Bilateral fixed and dilated pupils.

- Evidence of disease that interferes with outcome assessment.

- Evidence of alcohol intake.

- Associated cervical spine injury, blunt injury abdomen, chest injury, major crush injury of limb.

Patients in the study group were administered intravenous cerebroprotein hydrolysate $60 \mathrm{mg}$ bid for 14 days and then $60 \mathrm{mg}$ OD by intravenous infusion for 7 days. Cerebral dehydrant mannitol was given as $100 \mathrm{mg} 8$ hourly for 5 days, then tapered to $100 \mathrm{mg} 12$ hourly for 2 days and $100 \mathrm{~mL}$ OD for 2 days. The patients in the Control Group were administered citicoline $500 \mathrm{mg} 12$ hourly for 2 weeks. Injection dexamethasone $8 \mathrm{mg} 8$ hourly for 5 days and then
$4 \mathrm{mg}$ bid for 5 days. Intravenous antibiotics, proton pump inhibitors and intravenous fluids administered in both the groups were same.

\section{RESULTS}

The present study was conducted on 200 patients of TBI in the age group of 13 to 70 years with GCS $\leq 12$ from January 2016 to July 2017. Patients on cerebroprotein hydrolysate were compared with patients on conventional therapy (Control Group). Following observations were made and results were drawn from the study.

\section{Baseline Characteristics of the Patients}

\begin{tabular}{|c|c|c|}
\hline $\begin{array}{c}\text { Characteristic } \\
\text { (Age) }\end{array}$ & $\begin{array}{c}\text { Control Group No. } \\
\text { (\%) }\end{array}$ & $\begin{array}{c}\text { Study Group No. } \\
\text { (\%) }\end{array}$ \\
\hline 12-30 years old & $40(40 \%)$ & $42(42 \%)$ \\
\hline $31-45$ years old & $36(36 \%)$ & $28(28 \%)$ \\
\hline $46-60$ years old & $16(16 \%)$ & $24(24 \%)$ \\
\hline$>60$ years old & $8(8 \%)$ & $6(6 \%)$ \\
\hline Mean age & $36.16 \pm 14.61$ & $35.98 \pm 15.41$ \\
\hline Total & $\mathbf{1 0 0}$ & $\mathbf{1 0 0}$ \\
\hline
\end{tabular}

Table 1. Showing Incidence of TBI in Different Age Groups

Patients in age group of 12-30 years having most head injury cases (40\% in control group and $42 \%$ in study group) $(p=0.92)$. Mean age in control group is 36.16 and 35.98 in study $(\mathrm{p}=0.88)$. However, the difference was insignificant between the two groups.

\begin{tabular}{|c|c|c|}
\hline Sex & $\begin{array}{c}\text { Control Group No. } \\
(\%)\end{array}$ & $\begin{array}{c}\text { Study Group No. } \\
(\%)\end{array}$ \\
\hline Male & $74(74 \%)$ & $88(88 \%)$ \\
\hline Female & $26(26 \%)$ & $12(12 \%)$ \\
\hline Total & 100 & 100 \\
\hline
\end{tabular}

\begin{tabular}{|c|c|c|}
\hline $\begin{array}{c}\text { GCS at } \\
\text { Admission }\end{array}$ & $\begin{array}{c}\text { Control Group } \\
(n=100)\end{array}$ & $\begin{array}{c}\text { Study Group } \\
(n=100)\end{array}$ \\
\hline $\begin{array}{c}\text { GCS } 3-8 \text { with GCS } \\
\text { motor } \leq 5\end{array}$ & $36(36 \%)$ & $44(44 \%)$ \\
\hline $\begin{array}{c}\text { GCS } 9-12 \text { with GCS } \\
\text { motor } \leq 5\end{array}$ & $64(64 \%)$ & $56(56 \%)$ \\
\hline Mean \pm SD & $9.02 \pm 1.08$ & $8.58 \pm 1.11$ \\
\hline
\end{tabular}

At the time of admission, most patients were having GCS 9-12 (64\% in control group and 56\% in study group; $\mathrm{p}=0.58$ ). Mean GCS in the control group was 9.02 and 8.58 in study group $(\mathrm{p}=0.78)$.

\begin{tabular}{|c|c|c|}
\hline $\begin{array}{c}\text { Causes of Head } \\
\text { Injury }\end{array}$ & $\begin{array}{c}\text { Control Group } \\
(\mathbf{n = 1 0 0 )}\end{array}$ & $\begin{array}{c}\text { Study Group } \\
(\mathbf{n = 1 0 0 )}\end{array}$ \\
\hline $\begin{array}{c}\text { Road Traffic } \\
\text { Accident (RTA) }\end{array}$ & $52(52 \%)$ & $64(64 \%)$ \\
\hline H/O Fall & $28(28 \%)$ & $26(26 \%)$ \\
\hline Assault & $20(20 \%)$ & $10(10 \%)$ \\
\hline Total & $\mathbf{1 0 0}$ & $\mathbf{1 0 0}$ \\
\hline \multicolumn{2}{|c|}{ Table 4. Causes of Head Injury } \\
\hline
\end{tabular}

Table 4 shows that the most common cause of head injury was RTA (52\% in control group and $64 \%$ in study group). 


\begin{tabular}{|c|c|c|}
\hline $\begin{array}{c}\text { Plan of } \\
\text { Management }\end{array}$ & $\begin{array}{c}\text { Control Group } \\
(\mathbf{n = 1 0 0 )}\end{array}$ & $\begin{array}{c}\text { Study Group } \\
(\mathbf{n = 1 0 0 )}\end{array}$ \\
\hline Conservative & $82(82 \%)$ & $83(83 \%)$ \\
\hline Surgery & $18(18 \%)$ & $17(17 \%)$ \\
\hline \multicolumn{3}{|c|}{ Table 5. Plan of Management of Patients in both the } \\
Groups
\end{tabular}

Table 5 shows that conservatively managed patients were $82 \%$ in control group and $83 \%$ in study group, which is not significant.

\begin{tabular}{|r|c|c|c|}
\hline GCS at Discharge & Control Group & Study Group & P value \\
\hline GCS $($ mean \pm SD) & $12.69 \pm 1.02$ & $14.25 \pm 1.41$ & 0.48 \\
\hline Table 6. Showing GCS on Discharge \\
\hline
\end{tabular}

$P$ value $\leq 0.05$ is considered significant.

\begin{tabular}{|c|c|c|c|}
\hline & Control Group & Study Group & P value \\
\hline Days (mean \pm SD) & $6.25 \pm 0.04$ & $4.83 \pm 0.12$ & 0.045 \\
\hline \multicolumn{3}{|c|}{ Table 7. Days to Regain Full Consciousness } \\
\hline
\end{tabular}

$P$ value $\leq 0.05$ is considered significant.

Table 8- In study group, 60 (72.3\%) of 83 patients versus $60(73.2 \%)$ of 82 patients of control group have cognitive symptoms on discharge. 23 patients in study group and 22 patients in control group did not have any symptoms on discharge.

On follow-up at 1 month, 40 patients out of 60 (i.e. 60\%) belonging to the study group had cognitive symptoms, whereas in control group 56 (93\%) out of 60 patients had cognitive symptoms.

\begin{tabular}{|c|c|c|}
\hline Time & No. of Patients having Cognitive Symptoms \\
\hline & Control & Study \\
\hline Discharge & 60 & 60 \\
\hline 1 month & 56 & 40 \\
\hline 2 months & 20 & 22 \\
\hline 3 months & 14 & 16 \\
\hline \multicolumn{3}{|c|}{ Table 8} \\
\hline
\end{tabular}

We concluded that patients administered cerebroprotein hydrolysate (Study Group) showed statistical significance ( $\mathrm{p}$ value $=0.001$ ) in regards to GCS and in terms of functional and cognitive outcomes with time.

\section{DISCUSSION}

Traumatic brain injuries (TBI) are a steadily increasing and major cause of morbidity, mortality and loss of productivity in resource-limited settings, particularly among younger age groups. CNS injuries are divided into two main categories: primary which occur (mainly) at the moment of a trauma and secondary that develop after the initial injury.[5] The secondary injury process involves excessive synthesis of nitric oxide and oxidative stress, microglia activation, local inflammation, disturbance of microcirculation, blood-brain barrier dysfunction and the most recently acknowledged "delayed mechanisms of cell death." This leads to disastrous consequences of neuronal necrosis, neuronal apoptosis, scar and/ or cyst hygroma formation with further pathogenic effects on CNS tissue such as demyelination and disruption of morphofunctional nerve pathways. Secondary brain injury is the leading cause of hospital deaths after TBI.[6] Cerebroprotein hydrolysate $(\mathrm{CH})$ is a unique neurotrophic peptidergic mixture produced by standardised enzymatic breakdown of lipid-free porcine brain proteins.[7] It has unique neurotrophic activity that enhances neurogenesis, neuronal survival, provides neuromodulatory action, increases neuronal plasticity and neuronal repair and has neuro-immunotrophic actions. It has been found in animal studies that early intervention with cerebroprotein hydrolysate reduces permeability changes in blood-brain and blood-cerebrospinal fluid barriers, attenuates brain pathology and brain oedema and mitigates functional deficits caused by TBI.[8] Traumatic brain injury causes functional disability in the patient and only a handful of medications are available for its management.[9] As such, Cerebroprotein hydrolysate may prove to be beneficial in such patients. A complex study of cognitive and emotional status, levels of serum serotonin and brain-derived neurotrophic factor performed in 72 patients with acute TBI, with a special focus on middle brain injuries, treated with Cerebroprotein hydrolysate found that it promotes activation of neurotrophic processes and improves outcomes of closed craniocerebral injury.[10] Cerebroprotein hydrolysate is a medication that acts at the brain level and provides us with an effective tool for improving levels of activities of daily living in patients of head injury.[11] A double-blind, placebo-controlled, randomised study showed that Cerebroprotein hydrolysate improves the cognitive function of patients with mild TBI at $3^{\text {rd }}$ month after injury, especially for long-term memory and drawing function tested on MMSE and Cognitive Abilities Screening Instrument (CASI) scores. ${ }^{[12]}$

\section{Limitations of the Study}

Since the calculated sample size was too high and thereby not feasible to include in this limited period of study, we had to limit the sample size for convenience.

\section{CONCLUSION}

Our study concludes that use of cerebroprotein hydrolysate as part of the initial management of moderate and severe head injury is safe and well tolerated. The results suggest that Cerebroprotein Hydrolysate is beneficial in regard to the outcome in these patients and study proves that cerebroprotein hydrolysate therapy can be safe and useful in traumatic brain injury in terms of functional and cognitive outcome with better recovery.

\section{REFERENCES}

[1] Rimel RW, Giordani B, Barth JT, et al. Disability caused by mild head injury. Neurosurgery 1981;9(3):221-8.

[2] Ghajar J. Traumatic brain injury. Lancet 2000;356(9233):923-9.

[3] Kushner D. Mild traumatic brain injury: toward understanding manifestations and treatment. Arch Intern Med 1998;158(15):1617-24.

[4] Phirke M, Desousa A, Shah N, et al. The use of cerebroprotein hydrolysate in dementia: a cases series of 25 cases seen in a tertiary general hospital. Journal of Geriatric Mental Health 2014;1(2):106-9.

[5] Taber KH, Warden DL, Hurley RA. Blast-related traumatic brain injury: what is known? J Neuropsychiatry Clin Neurosci 2006;18(2):141-5. 
[6] Karia S, Mahajan PT, Shah N, et al. Cerebroprotein hydrolysate in traumatic brain injury. El Mednifico Journal 2014;2:34-5.

[7] Jain N, Yadav S, Goyal M, et al. Cerebroprotein hydrolysate: innovation in neurodegenerative disorders. IJMDS 2014;3(1).

[8] Faul M, Xu L, Wald MM, et al. Traumatic brain injury in the United States: national estimates of prevalence and incidence, 2002-2006. BMJ 2010;16(Suppl 1).

[9] Langlois JA, Rutland-Brown W, Wald MM. The epidemiology and impact of traumatic brain injury: a brief overview. J Head Trauma Rehabil 2006;21(5):375-8.
[10] Brain injury: causes \& symptoms. Available at: www.gillettechildrens.org/default.cfm? July 2011.

[11] Skvortsova VI, Stakhovskaia LV, Gubski LV, et al. A randomized, double-blind, place controlled study of cerebrolysin safety and efficacy in treatment of acute ischemic stroke. Zh Nevrol Psikhiater im S S Korsakova 2004;(Suppl 11):51-5.

[12] Wornski R, Kronawetter S, Hutter-Paier B, et al. A brain derived peptide reduces the translation dependent loss of a cytoskeletal protein in primary cultured chicken neurons. J Neural Transm Suppl 2000;59:263-72. 